\title{
Analisis Bentuk Musik atas Kesenian Laras Madya dan Resistensinya dalam Budaya Jawa
}

\author{
Sagaf Faozata Adzkia \\ Program Studi Pendidikan Seni, Program Pascasarjana, Universitas Negeri Semarang \\ E-mail: adzkia_sagaf@yahoo.com
}

\begin{abstract}
The Laras madya is a development form of Santiswaran music from the time of Pakubuwono X (1893-1930) in Kasunanan Surakarta. This is a Javanese-Islamic cultures blend of music that its song lyric is based on the Serat Wulangreh text written by Pakubuwono IV. The Laras Madya instrumentation is generally utilized traditional percussions such as the kendang, the terbang dhana, the terbang gong, and the two-pitches saron, to accompany the Bowo (solo singer), and the Gerong (accompanist singer). This study discusses the uniqueness of Larasa Madya's musical form and its resistance from the domination of mass culture. Therefore, this research is aimed to describe and analyze the Laras madya's musical form, and the resistance. This study applies interdisciplinary approaches to musicology, cultural studies, and socio-anthropology, through qualitative methods. This study result indicates that the Laras madya is a form of Javanese ensemble which characterized by rhythm repetition, the use of the Slendro pentatonic melody, constant expression, and moderate-andante tempo. To resist from the hegemony of mass culture, the Laras Madya owns some efforts to form such public opinion/ campaign through cultural festival media, as its open resistance characteristic, and also to raise rumors on the negative image of mass culture as a class domination that is conducted bt individuals, as the trait of closed resistance.
\end{abstract}

Key Words: Laras Madya; Musical Form; Resistance.

\begin{abstract}
Abstrak
Laras Madya merupakan seni musik pengembangan bentuk Santiswaran pada masa Pakubuwono X (1893-1930) di Kasunanan Surakarta. Sebuah musik perpaduan kebudayaan Jawa Islam yang menggunakan Serat Wulangreh karya Pakubuwono IV sebagai tembang syairnya. Instrumentasi Laras madya pada umumnya menggunakan kendang, terbang dhana, terbang gong, dan saron dua bilahan yang berguna mengiringi bowo (penembang utama), dan gerong (penembang pengiring). Keunikan bentuk musik dan resistensi Laras Madya dari dominasi budaya massa merupakan permasalahan yang diangkat. Tujuan penelitan ini berguna untuk mendeskripsikan dan menganalisis bentuk musik Laras Madya dan resistensinya. Pendekatan penelitian ini mengguanakan interdisiplin melalui ilmu musikologi, cultural studies, dan sosio-antropologi, dengan metode kualitatif. Hasil penelitian menunjukkan, Laras Madya merupakan sebuah bentuk ansambel musik Jawa yang memiliki irama dengan ciri repetisi, melodi didominasi tangga nada pentatonik slendro, ekspresi cenderung konstan sebagai lagu renungan religi pada umumnya, bertempo sedang (moderato-andante). Dalam ketahanannya pada hegemoni budaya massa, Laras Madaya memiliki upaya pembentukkan opini publik/kampanye melalui media festival budaya yang ada, sebagai ciri resistensi terbuka, dan pergunjingan pencitraan negatif terhadap klas dominasi budaya massa yang dilakukan secara individual, sebagai ciri resistensi tertutup.
\end{abstract}

Kata Kunci: Laras Madya; Bentuk Musik; Resistensi.

\section{Pengantar}

Lahir dan terilhami dari gendingan Santiswaran pada masa Paku Buwono X di Kasunanan Surakarta, Laras Madya dikemas dengan pengembangan yang lebih "njawani", yaitu melalui penggunaan teks yang mempedomani Serat Wulangreh. Serat Wulangreh merupakan seni sastra karya Susuhunan Pakubuwono IV, berbahasa Jawa, berisikan 
pedoman tuntunan hidup bagi masyarakat yang tak lepas dari tun-tunan agama Islam.

Pada umumnya Laras Madya dibawakan dengan menggunakan iringan instrumen musik kendhang, terbang dhana (rebana kecil), terbang gong (rebana besar), dan saron dengan hanya dua bilah nada. Perpaduan alat musik/ansambel tersebut digunakan untuk mengiringi tembang yang dilantunkan seorang Bowo (penembang utama), dan Gerong (koor pengiring). Bentuk penyajian dari Laras Madya tergantung pada kreativitas daerah atau kelompok tertentu, spesivikasi perbedaannya dengan Santiswaran adalah penggunaan cakepan Jawa, dari pada sebelumnya yang terdapat unsur bahasa Arab (Supanggah, 2009:162).

Secara etimologi kata laras merupakan harmoni atau tangga nada, madya berarti tengah, jika dua kata tersebut digabungkan memiliki makna nada/tembang tengahan. Secara harfiah dapat diartikan sebagai sebuah seni musik yang memiliki nilai keseimbangan dalam pemahaman nilai-nilai kehidupan, yaitu keseimbangan nilai budaya Jawa sebagai identitas kesukuan dan Islam sebagai ideologi keagamaan.

Para pelaku seni musik di Sleman Yogyakarta, Bapak Bowo menuturkan, awal mula Laras Madya tersebar sampai ke daerahnya adalah pada tahun 1963. Disiarkan oleh Mohamad Salman, masyarakat setempat memanggilnya Mbah Kyai Salman, sebutan Mbah Kyai adalah simbol untuk pemuka agama Islam masyarakat Jawa pada umumnya, ia merupakan putra abdi dalem keraton Surakarta yang bernama Faqih Ibrahim tangan kanan kepercayaan Pakubuwono X. Mbah Kyai Salman kemudian mendapatkan amanah untuk menyebarkan musik Laras Madya ke luar keraton Surakarta.

Salah satu penyebaran musik Laras Madya tersebut masih bisa didapati keberadaanya hingga saat ini di Dusun Sucen, Kelurahan Triharjo, Kecamatan Sleman, Yogyakarta. Tersampainya Laras Madya sebagai media syiar Islam tersebut, merupakan penggambaran sebuah produk kebudayaan Jawa Islam yang dinamis tidak terbentur kekakuan-kekakuan adat dan relijiusitas. Sebagaimana kebudayaan tetap responsif terhadap perubahan kondisi dari dunia fisik, oleh karena itu kebudayaan bersifat dinamis (Liliweri, 2014:33).

Laras Madya merupakan salah satu wujud kreativitas yang dilakukan oleh para penyiar agama Islam. Dilakukan dengan memadukan nilai-nilai Islam dengan budaya Jawa, sehingga Islam dapat diterima secara sadar, tanpa paksaan, damai, dan tidak menimbulkan berbagai macam gesekan idiologis pada masyarakat. Sebagaimana ciri khas budaya Jawa yang mengutamakan keharmonisan (Sulasman dan Gumilar, 2013:173).

Keberadaanya kini, Laras Madya menempati hirarki folk art, yang tumbuh di dalam keutuhan folk culture, suatu gambaran musik tradisional yang berada di tengah-tengah kebudayaan rakyat, sebagai material penyangga keberadaan kebudayaan rakyat. Hal tersebut didasari dengan beberapa klasemen seni yang tergolongkan menjadi empat bagian kategori yaitu seni untuk kalangan elit (The Art of Cultural Elite), seni rakyat (folk art, seni populer atau seni kalangan urban (popular art, dan seni yang dipertunjukkan melalui media masa (mass art) (Hauser, 1982: 556).

Pada keberlangsungan budaya massa saat ini, segala sesuatu diproduksi secara masal guna memperoleh sebuah keuntungan, musik tradisi diposisikan pada situasi yang menyulitkan. Budaya massa adalah sebuah budaya komersial, produk masal untuk pasar masal (Sunarto, 2014:112), yang memposisikan masyarakat sebagai konsumen pasif pada setiap produk baik barang maupun jasa yang bersifat komersil, termasuk pula berbagai macam seni massa/mass art yang ramai di berbagai media. Budaya massa mempengaruhi seni sebagai sebuah produk yang berkembang. Banyaknya seni massa termasuk musik didalamnya menjamur dan bebas dikonsumsi menyebabkan musik 
tradisi baik secara sadar ataupun tidak memerlukan kerja keras untuk bersaing, berbeda dengan seni massa hasil budaya massa yang mudah difahami, musik tradisi cenderung lebih sederhana dan memerlukan pengamatan ekstra dalam penyampaiannya, termasuk dinamika geliat kebertahanan Laras Madya di Yogyakarta.

Keberadaan dan kebertahanan Laras Madya di tengah masyarakat tentunya tak lepas dari perjalanan panjang para pelakupelakunya dalam berproses menyajikan bentuk musiknya yang menarik, serta upaya bertahan/resistensi dari dominasi budaya massa yang berkembang pesat. Berdasarkan fenomena yang terjadi, peneliti mengambil dua poin permasalahan yaitu bagaimanakah bentuk musik Laras Madya?, dan bagaimanakah proses resistensinya? Tujuan penelitian ini berguna untuk mendeskripsikan dan menganalisis bentuk musik Laras Madya, serta mendeskripsikan dan menganalisis proses resistensinya.

Penelitian ini menggunakan pendekatan interdisiplin, dalam pengertianya yaitu menggunakan lebih dari satu disiplin ilmu menjadi sebuah penggabungan dalam mengkaji permasalahan (Rohidi, 2011: 61). Secara rinci menggunakan disiplin ilmu Musikologi melalui konsep dari Jamalus guna mendeskripsikan dan menganalisis bentuk musik, Cultural Studies sebagai pisau bedah dinamika hegemoni budaya massa, melalui konsep komunikasi bujuk-rayu (seduction), oleh Baudrillard, dan disiplin ilmu Sosio-Antropologi melalui teori resistensi James Scott guna menganalisis kebertahanannya.

Metode yang digunakan adalah metode kualitatif. Dalam penelitian kualitatif data yang akan muncul berwujud kata-kata dan bukan rangkaian angka, dengan pengumpulan data menggunakan observasi, wawancara, studi dokumen kemudian diproses dan dianalisis. Sasaran kajian dalam penelitian ini adalah seni Laras Madya, yang difokuskan pada bentuk musik, dan proses resistensinya. Teknik keabsahan data secara utama menggunakan triangulasi sumber, lalu kemudian dianalisis secara interaktif.

\section{Pembahasan}

Pembahasan dalam penulisan ini di bagi menjadi duah paparan. Yang pertama adalah mengenai bentuk musik Laras madya, dan yang kedua adalah proses resistensinya, berikut penjelasannya:

\section{Bentuk Musik Laras Madya}

Berbicara bentuk musik tentu saja tak lepas dari susunan struktur yang terkait satu sama lain didalamnya. Struktur atau susunan dari suatu karya seni musik adalah aspek yang menyangkut keseluruhan dari sebuah karya yang meliputi peranan dari masing-masing bagian yang tak terpisah saling melengkapi satu sama lain. Sejalan dengan hal tersebut diatas musik merupakan suatu karya seni yang berbentuk lagu atau komposisi yang mengungkapkan perasaan dan pikiran penciptanya melalui unsur-unsur musik seperti irama, melodi, harmoni, bentuk, dan struktur lagu, serta ekspresi (dinamika) menjadi satu kesatuan yang utuh (Jamalus, 1988:1). Berkaitan dengan konsep terebut Laras Madya dapat dijabarkan melalui unsur-unsur musik yang terdapat didalamnya.

Musik Laras Madya sangat khas, merupakan sebuah kesatuan ansambel dari instrumen kendang, terbang dhana, terbang gong, dan saron dua bilahan. Guna lebih memahami, sebelumnya akan ditampilkan notasi 8 birama dari tema pokok bentuk musik laras madya. Delapan birama mewakili keseluruhan permainan, di-karenakan pembawaan musik Laras Madya merupakan repetisi-repetisi tema pokok, yang membedakan adalah variasi pada sifat beberapa judul lagu yang disajikan. Dapat dilihat dari notasi tersebut bahwa irama musik Laras Madya merupakan repetisi-repetisi dari teknik ansambel perkusif melalui perpaduan 
masing-masing instrumen yang saling mengisi melengkapi satu sama lain.

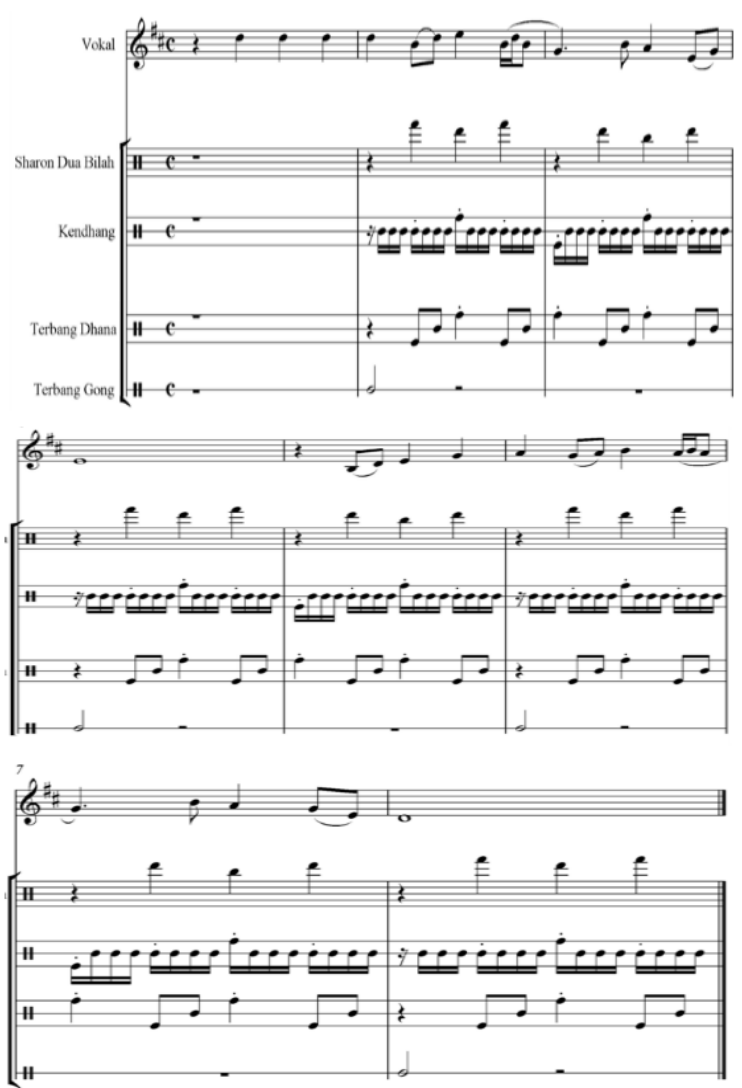

Ilustrasi 1.

Notasi Tema Bentuk Musik Laras Madya (Notasi: Sagaf)

Sifat irama cenderung monoton namun justru disitu letak ke khasan dari penyajian lagu-lagunya. Kendang berfungsi penuh sebagai alas dan juga pemimpin ansambel tersebut, ia sebagai komando untuk memulai lagu, pengatur tempo, pembangkit sifat dari sebuah lagu melalui variasi-variasi irama yang dimainkan dikarenakan kendang memiliki peran yang lebih atraktif dibanding instrumen-instrumen yang lain-nya.

Terbang dhana berperan sebagai penegas dari hasil olahan suara kendang, menjadikan olah bunyi dari kendang terdengar semakin mantap karenanya. Terbang gong berfungsi sebagai bass, dibunyikan setiap dua birama sekali pada hitungan awal birama ganjil, yang menjadikan keseluruhan bunyi musik terdengar berbo- bot sebagai pijakan pada dasar (ground). Saron memiliki fungsi yang unik, dimainkan pada keutuhan lagu setiap pada hitungan ke 2-4 pada setiap birama, saron muncul sebagai ciri khas dari laju musik Laras Madya dengan bunyi statis "ning..nong..ning" begitu terusmenerus sampai lagu berakhir.

Melodi pada nada pentatonis Jawa terbagi menjadi dua yaitu pelog dan slendro. Melodi yang terdapat dalam musik Laras Madya pada umumnya menggunakan pentatonis slendro, terdiri dari lima buah rangkaian nada biasa diistilahkan dalam angka Jawa ji untuk 1, ro untuk nada ke 2 , lu untuk nada ke 3, mo untuk nada ke 5, dan nem untuk nada ke 6 . Berikut rangkaian nadanada slendro dalam penulisan notasi balok.

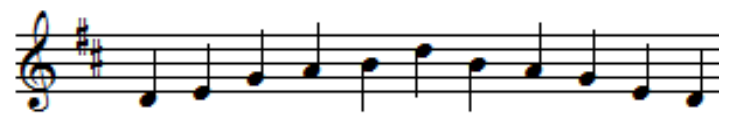

Ilustrasi 2.

Rangkaian Nada Pentatonis Slendro (Foto: Sagaf)

Dalam penyajian musik Laras madya, nada slendro digunakan dalam keutuhan lagu. Baik saat suluk sebagai pembuka lagu (bait intro) yang dibawakan secara improvisasi ritmikal namun tak lepas dari ketentuan interval slendro ataupun inti dalam pembawaan materi lagu tersebut.

Secara umum harmoni musik yang terdapat dalam Laras Madya adalah harmoni horisontal. Alat musik pengiring sepenuhnya bersifat perkusif, tidak bernada secara otentik terkecuali saron, sedemikianpun saron pada Laras Madya hanya memiliki dua nada yang tidak sepenuhnya terpaut dengan nada-nada yang dibawakan oleh pelantun tembang bowo dan gerong. Variasi harmoni terdapat dalam koor yang dibawakan oleh gerong dalam merespon lantunan tembang bowo, namun koor yang dibawakan gerong bersifat monoponik. Sebuah nyanyian bersama-sama menggunakan satu suara/similar dengan melodi tembang 
utama yang berguna mempertegas sebuah nyanyian.

Bentuk struktur lagu Laras Madya diawali dengan suluk oleh penyaji tembang utama (bowo). Suluk berfungsi sebagai intro dengan penyampaian bait pembuka dari syair Serat Wulangreh. Merupakan sebuah musikalisasi syair dibawakan secara solo, improvisasi dengan menggunakan modus tangga nada/ pentatonik slendro. Variasi ritmik dan interval nada dari modus tersebut dibawakan berdasarkan kebebasan penembang utama, semakin bervariasi ritmik, interval, dan intensitas tempo menandakan kepiawaian seorang bowo. Tabuhan kendang sebagai feel in menandai dimulainya inti lagu yang dibawakan diikuti instrumen-instrumen musik yang lainnya dan berjalan sesuai masing-masing patren yang menjadi patokannya. Hal tersebut dilakukan terus-menerus dalam repetisi guna mengiringi lantunan tembang dari syair lagu. Di penghujung syair kendang mendireksi alat musik lainnya guna memperlambat tempo (ritardando), lalu lagu diahiri dan ditutup dengan tabuhan terbang gong dalam satu ketukan terahir.

Ekspresi yang terdapat dalam musik Laras Madya umumnya relatif konstan, seperti sifat sebuah lagu renungan religius pada umumnya yang memiliki keanggunan dalam makna. Pada rangkaian lagu-lagu yang dibawakan diawali dengan lagu yang relatif rancak (tempo moderato), lalu ber-angsur berganti lagu yang kian lambat dan mendayu. Namun perbedaan tempo terjadi pada lagulagunya tidak secara tiba-tiba dan drastis. Pelambatanya tidak mengalami ketimpangan yang berarti ( moderato di awal dan andante di lagu-lagu terahir).

\section{Instrumen yang digunakan dan peran- annya}

Sebagai gambaran untuk mem-perjelas bentuk musik Laras Madya, berikut penjelasan instrumentasi beserta perannya. Pertama ialah kendang yang merupakan sebuah in- strumen perkusi yang berasal dari kebudayaan Jawa dengan sebuah tabung dari kayu, (kayu nangka, kayu mahoni) dengan membran dari bentangan kulit lembu. Kendang merupakan alat musik membranofon, sebagai pengisi perkusi pada orkestra gamelan, keberadaanya tersebar sehingga juga terdapat kendang Sunda, kendang Jawa, kendang Bali, dalam cirikhas masing-masing yang berbeda.

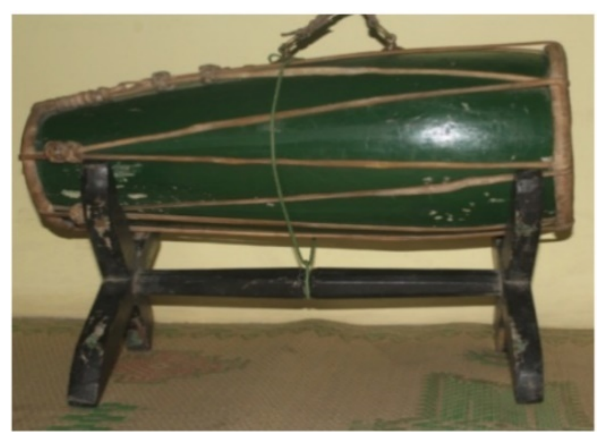

Ilustrasi 3.

Instrumen Musik Kendang (Foto: Sagaf)

Dalam musik Laras Madya yang digunakan adalah kendang Jawa tunggal. Berfungsi sebagai pengatur tempo dan memimpin instrumen lain. Penabuh kendang memiliki fungsi seperti kondakter dalam orkestra.

Instrumen berikutnya ialah Terbang, diperkirakan berasal dari kebudayan Islam. Terbang terbesar ialah Terbang Gong yang diameternya melebihi kendang, yaitu berdiameter $50-60 \mathrm{~cm}$.
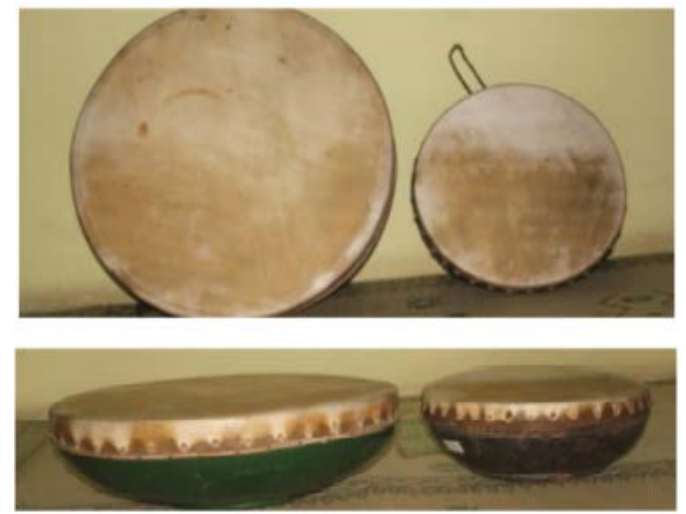

Ilustrasi 4.

Instrumen Musik Terbang Gong dan Terbang Dhana (Foto: Sagaf) 
Terbang Gong berfungsi sebagai bass. Fungsi terbang ini ialah mengisi ritmik sederhana pada setiap permulaan dua birama sekali, menjadikan musik yang tersaji terdengar berat dan berbobot. Sementara itu terbang dhana yang berdiameter $40 \mathrm{~cm}$ memiliki kemiripan dengan terbang gong. Instrumen ini berfungsi sebagai isian variasi perkusi yang mengikuti kekosongan ritmik dengan komando tempo dari kendang. Terbang Dhana penting karena menjadikan penyajian musik Laras Madya terdengar penuh.

Instrumen berikutnya ialah Saron. Instrumen ini merupakan salah satu instrumen gamelan yang termasuk dalam keluarga balungan, biasa disebut juga "ricik". Ditabuh dengan cara dipukul dengan alat pemukul menyerupai palu yang terbuat dari kayu.

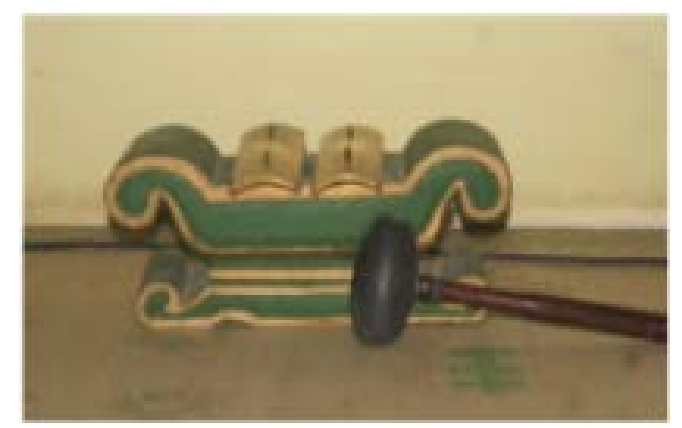

Ilustrasi 5.

Instrumen Musik Saron Dua Bilahan (Foto: Sagaf)

Keunikanya dalam kesenian Laras Madya, ialah saron yang dipakai hanya memiliki dua buah bilah balungan, bernada 6 dan 7 (nem dan pi). Merupakan dua rangkaian bilah dari perunggu terlihat kecil diantara instrumen-instrumen yang lainya, memiliki warna suara yang unik berbunyi " ning dan nong" yang merupakan warna suara ciri khas kesenian musik Laras Madya.

Di samping seperangkat instrumen Kesenian Laras Madya berang-gotakan pelantun tembang yang disebut Bowo dan Gerong. Bowo merupakan penyanyi bait-bait pembuka, semacam intro yang tidak diiringi musik. Lazimnya Bowo dibawakan oleh seseorang yang dianggap mumpuni, sesepuh atau pemimpin kelompok. Seorang yang berperan sebagai Bowo ini harus benar-benar ahli tembang, karena Bowo merupakan leader untuk memulai lagu, maka suara pelantunnya harus benar-benar mantap. Hanya saja, dari satu tembang ke tembang berikutnya, bowo tidak dibawakan oleh seorang saja, namun kadang berganti dengan personil lain yang sama-sama mumpuni.

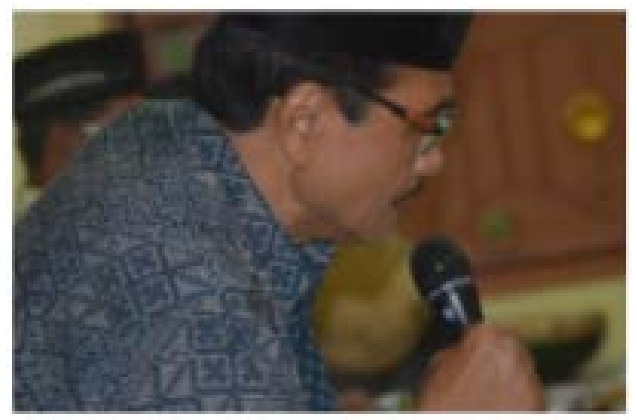

Ilustrasi 6.

Pelantun Tembang (Foto: Sagaf)

Gerong merupakan pemain Laras Madya yang tidak memainkan alat musik namun berpartisipasi dalam memberikan "Senggakan" atau aksentuasi vokal dan "tepuk tangan" sebagai pengiring ritmikal yang melengkapi penyajian musik Leras Madya.

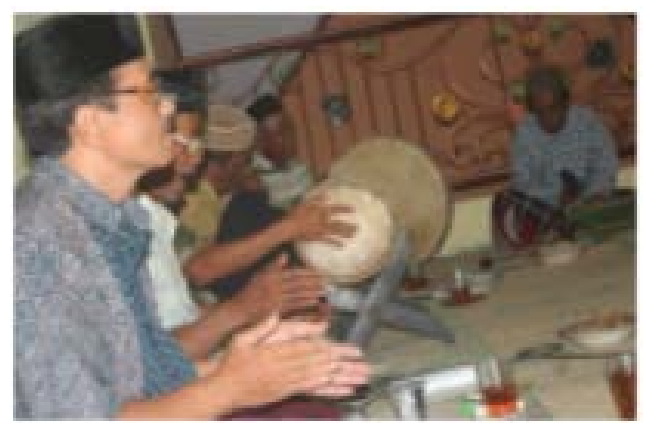

Ilustrasi 7.

Penyajian Kesenian Laras Madya (Foto: Sagaf)

Senggakan bisa berupa suara-suara sahutan yang menutup (seperti sebuah kata yha'e..!!), menyusuli ataupun menyelaraskan 
ketukan dengan irama tembang. Adapun iringan tepukan tangan berfungsi merampakkan alunan musik sehingga menjadi hidup dan meriah. Gerong sangat terbuka bagi partisipasi audiens asalkan tidak merusak keseriusan penyajian.

Syair dari Serat Wulangreh merupakan syair utama yang digunalan dalam musik Laras Madya.buah karya sastra dari Susuhunan Pakubuwono IV. Syair tersebut berisi tuntunan hidup masyarakat jawa dengan kaidah-kaidah keIslaman.

Berikut adalah syair Serat Wulangreh ("kriteria guru yang baik" menurut Paku Buwana IV) dalam musik Laras Madya menurut teks bahasa Jawa:

Sasmitaning ngaurip puniki,
yekti ewuh yen ora weruha,
tan jumeneng ing uripe,
sakeh kang ngaku-aku,
pangrasane pan wus utami,
tur durung wruh ing rasa,
rasa kang satuhu,
rasaning rasa punika,
upayanen dhara pon, sapurneng dhiri, ing
kaupanira.
Jroning Qur'an nggoning rasa jati,
nanging pilih wong kang uninga,
anjaba lawan tuduhe nora kena binawur,
ing satemah nora pinanggih,
mundak katalanjukan,
temah sasar-susur,
yen sira ayun waskitha,
kasampurnaning badanira puniki, sira angge-
gurua.
(Pupuh Dhandhanggula pada 2-3)

Berikut terjemahannya dalam bahasa Indonesia:

Maka kehidupan itu sungguh sayang sayang bila tak tahu, tidak kokoh hidupnya, banyak orang mengaku, perasaanya sudah utama, padahal belum tahu rasa, rasa yang sesungguhnya, hakikat rasa itu adalah, usahakan supaya diri sempurna,dalam

kehidupan.

Dalam Qur'an tempat rasa jati

tapi jarang orang tahu,

keluardari petunjuk,

tak dapat asal-asalan,

ahirnya tidak ketemu,

malahan terjerumus,

akhirnya kesasar,

kalau kamu ingin peka,

agar hidupmu sempurna,

maka bergurulah.

\section{Resistensi Budaya Musik Laras Madya}

Resistensi memiliki makna yang sangat luas untuk dipahami, namun pada dasarnya dapat dikaitkan dengan terjadinya sebuah perlawanan yang dilakukan sub baltern atau mereka yang tertindas dan menjadi subjek yang tertekan oleh karena ketidakadilan klas-klas dan sebagainya. Resistensi juga dapat dilihat sebagai materialisasi atau perwujudan yang paling aktual dari hasrat untuk menolak dominasi pengetahuan atau kekuasaan (Hujatnikajennong, 2006:176).

Berbeda dengan istilah konfrontasi yang memposisikan subjek secara langsung terang-terangan dalam sebuah bentuk pertentangan, resistensi lebih pada posisi yang memiliki kecenderungan dengan bentuk ketidak patuhan, penolakan terhadap kondisi klas dominan yang tidak sukai. Bentuk resistensi secara diam-diam atau terselubung dari eksploitasi adalah lebih umum daripada melawan secara terang-terangan (Alisjahbana, 2005:22-23).

Konsep resistensi adalah bentuk resistensi sehari-hari (every day forms of resistance), yang merupakan perjuangan yang biasa-biasa saja, namun terjadi terus-menerus. Kebanyakan resistensi dalam bentuk ini tidak sampai pada taraf pembangkangan terang-terangan secara kolektif. Resistensi merupakan segala tindakan kelompok subordinat yang ditujukan untuk mengurangi atau menolak klaim kelompok superdinat. Resistensi dibagi menjadi dua, yakni resistensi terbuka dan tertutup. Teoriresistensi 
terbuka/ public transcript, dan resistensi tertutup/ hidden trancript (Scott, 1990:1-5).

Kedua bentuk resistensi memiliki masing-masing klasifikasi. Resistensi terbuka bersifat Organik, sistematik dan kooperatif, tidak mementingkan kepentingan diri sendiri, berkonsekuensi revolusioner, mencakup gagasan atau maksud meniadakan basis dominasi. Resistensi tertutup dicirikan dengan pola-pola yang tidak teratur, tidak sistematik, dan terjadi secara individual, bersifat oportunistik dan mementingkan diri sendiri, tidak berkonsekuensi revolusioner, lebih akomodatif terhadap sistem dominasi (Scott, 2000: xxii-iv).

Budaya massa merupakan budaya komersial berjalan melalui teknik-teknik produksi masal sedemikian rupa kemudian dipasarkan terhadap masyarakat luas/ massa/ konsumen secara komersial. Dengan adanya fenomena tersebut budaya massa secara umum disebut juga sebagai budaya komersial yang tak langsung memiliki kecendrungan menyingkirkan bentuk-bentuk kebudayaan lain yang tak dapat bertahan dalam klas-klasnya. Sepaham dengan tesis homogenisasi kultural, sebagaimana bentuk imperialisme kultural yang menekankan 'kesamaan' sebagai dugaan akan hilangnya otonomi kultural. Argumen tentang globalisasi kapitalisme konsumen menghilangkan keragaman kultural, merupakan bentuk atas dominasi kebudayaan atas kebudayan yang lainnya, biasanya dipahami ber-dasarkan konteks kebangsaan. Sinkronisasi kebudayaannya adalah perusahaan-perusahaan trans-nasional (Hamelink dalam Barker, 2015:121).

Dengan terjadinya perkembangan budaya massa melalui komoditi-komo-cditinya maka terjadi pula pertentangan-pertentangan ideologi, yaitu makna ideologis yang tersampaikan oleh budaya massa melalui media sebagai agen atas komoditi-komoditinya, bertentangan dengan makna-makna tradisional. Sifat-sifat tontonan dalam media diatas seperti kesenangan, penampakan pada media massa, dan komoditi, dalam beberapa sisi telah mengendurkan nilai dan makna moralitas, tabu, spiritial, adat-istiadat, dan mitologi (Sunarto, 2014:128).

Hegemoni budaya massa dapat dilihat melalui konsep Baudrillard, tentang lahirnya prinsip komunikasi baru yang disebut sebagai prinsip bujuk-rayu (seduction). Bila sebelumnya komunikasi dipahami sebagai proses penyampaian pesan dari pemberi pesan (addresse) kepada penerima pesan (address) untuk diperoleh suatu makna tertentu, maka kini komunikasi dipahami sebagai proses bujuk-rayu objek (konsumen) oleh subjek (produsen) untuk mengkonsumsi produk-produk yang ditawarkan. Melalui iklan, kampanye, tayangan talkshow, dan gempuran media massa (Baudrillard dalam Sunarto, 2014:123).

Musik sebagai komoditi budaya masa salah satunya dapat dirasakan melalui menjamurnya tayangan produksi masal bertajuk acara-acara kompetisi dengan audiens melalui pesan singkat sebagai juri eksekutor pada media pertelevisian. dominasi tayangan tersebut tak pandang bulu jam tayang, pesan yang tersampaikan, semua berdasar keuntungan mendapatkan posisi yang tingggi pada rating acara, dengan tujuan profit sebagai sasaran utama. Hal tersebut mendominasi setiap acara pertelevisian yang ada, masyarakat dihadapkan pada situasi yang sama secara terus-menerus sebagai konsumen pasif target produksi.

Makna dari dominasi tayangan-tayangan tersebut tidaklah penting, konsep seduction sangat terlihat jelas didalamnya. Tambahan bujuk rayu yang ada dibarengi dengan tayangan- tayangan iklan yang mengiringi, produk digambarkan melebihi nilai realitas yang dipasarkan pada masyarakat, terlihat dengan kemasan yang jauh lebih menarik, dan rayuan manis dari bintang iklan yang mempromosikan. Budaya massa dengan produk musik yang sejalan didalamnya membentuk pola-pola baru dengan materi produksi yang jauh dari makna realitas 
dengan harapan sebagai pusat sasaran baru yang dijadikan panutan pada setiap mata yang memandang pada masyarakat umum. Televisi memuat segala macam karakter postmodernisme: reproduksi, manipulasi, simulasi, simularca, bujuk rayu, dan hiperrealitas dengan tampilan yang paling menawan dan menggiurkan (Sunarto, 2014:142).

Resistensi Laras madya dapat dilihat melalui keberadaanya hingga saat ini dalam berbagai peran yang ada. Kebertahanannya secara sadar atau tidak merupakan suatu langkah oposisi dari gempuran budaya masa yang ada. Resistensi terbuka Scott dalam mengamati bentuk ketahanan Laras Madya dapat dilihat dengan adanya seni tersebut pada beberapa festival/kompetisi seni tradisi sebagai upayanya. Supanggah mengungkapkan Laras Madya sebagai bentuk pertunjukkan pernah menjadi materi yang menarik perhatian bagi generasi muda. Begitupun dengan adanya lomba dan festival Laras Madya yang marak pada kurun waktu tahun 1970-1980an di Surakarta (Supanggah, 2009:163).

Kemerosotan keberadaan Laras Madya saat ini bukan tak dapat dijumpai sama sekali, walaupun tidak sesemarak dahulu, keberadaan dan bentuk resistensi terbukanya masih dapat dijumpai beberapa waktu terahir. Salah satu contohnya yaitu dengan adanya "Festival Budaya Islami" di Pukis Minggir Sleman, tahun 20013, dengan Laras Madya yang berperan didalamnya. Bentuk festival seperti yang telah terselenggara merupakan sebagai wujud dari resistensi terbuka karena memenuhi aspekaspek yang terkandung, seperti bersifat organik, sistemik dan, kooperatif. Bisa dikatakan organik karena Laras madya berada dalam festival melalui pengaturan sebuah sistem yang terorganisir dengan jelas.

Sifat organik, sistemik, dan kooperatif, pada resistensi musik Laras Madya dapat dilihat melalui pengaturan interen pada sebuah grup ataupun dalam proses kinerja kelompok memasuki wilayah kepanitiaan penyelenggara festival melalui beberapa tahapan formal yang wajib di lalui yang terkait secara teratur dan logis. Hal- hal tersebut tentu saja dilakukan dalam sebuah bentuk kerjasama komunitas sosial pada setiap elemen yang berkaitan didalamnya. Kerjasama tersebut bisa antar kelompok seni yang ada dalam sebuah festival, ataupun kelompok sosial masyaratak kepanitiaan penyelenggara.

Poin alasan resistensi terbuka yang kedua adalah tidak mementingkan diri sendiri. Laras madya merupakan sebuah bentuk grup, hal tersebut tentu saja bersifat komunal, resistensi berdasar pada kepentingan bersama, yaitu misi keber-samaan dalam grup dan atau misi umum terselenggaranya festival tersebut.

Berkonsekuensi revolusioner merupakan ciri resistensi terbuka pada poin ketiga. Hal tersebut dimaksudkan dengan memiliki pemikiran bersesuaian dengan misi yang dituju, yaitu sebuah perubahan sosial budaya yang berlangsung cepat mencangkup pokok kehidupan masya-rakat. Tergerusnya kehidupan tradisi oleh menjamurnya budaya massa mengkha-watirkan pelaku seni tradisi, pandangan masyarakat terfokus pada tren-tren baru produksi massa di setiap media yang ada. Misi yang dituju dalam Festival Budaya Islami tak lepas dari sebuah pemikiran yang bersesuaian dengan membentengi gempur-an negatif budaya massa. "Nguri-uri kabudayan lan agama" merupakan ungkapan yang bermakna yang digunakan sebagai simbol pengingat masyarakat akan batasan-batasan terhadap dampak buruk ideologi massa. Guna mencintai tradisi sebagai akar budaya masyarakat yang bermakna.

Poin keempat pada teori resistensi terbuka adalah mencakup gagasan dengan maksud meniadakan basis dominasi. Tindakan-tindakan terorganisir dalam Festival Budaya Islami tersebut merupakan contoh pemahaman oposisi dari men-jamurnya budaya massa. Kaitannya adalah ungkapan dan 
pemahaman dari tokoh seni terkait yang memuat kritik sosial sebagai lawan dari gempuran ideologi massa yang ada. Tersampainya pemikiran akan pentingnya budaya tradisi pada asyarakat umum merupakan simbol perlawanan sebagai manifestasi untuk menghindari kebaruan-kebaruan yang tak berkenan. Dengan harapan masyarakat mengabaikan hegemoni budaya massa yang menjadikan faham-faham konsumerisme sebagai muatan utamanya.

Bentuk-bentuk festival kebudayaan seperti yang telah dicontohkan merupakan sebuah media subaltern dalam menyampaikan pemikiran-pemikirannya. Bahwasanya seni tradisi memiliki nilai yang lebih bermanfaat ketimbang produk-produk budaya massa adalah upaya kampanye atau pembentukkan opini publik, dimana kampanye atau pembentukkan opini publik merupakan salah satu dari upaya perlawanan terbuka (Scott, 1990:32-50).

Aspek pertama dalam bentuk resistensi tertutup adalah sebuah kegiatan yang tidak teratur, tidak sistemik, dan terjadi secara individual. Hegemoni budaya massa yang terpublikasi secara terus-menerus melalui berbagai media massa, seringkali memuat sikap-sikap yang bertolak belakang dengan kehidupan masyarakat tradisi yang penuh norma kesopanan. Tayangan pertelevisian didomonasi sikap gaya hidup glamor ciri khas masyarakat perkotaan yang jauh dari sikap penuh "unggah-ungguh". Dalam keadaan seperti ini muncul pencitraan negatif masyarakat tradisi termasuk pelaku seni musik Laras Madya didalamnya. Pengungkapan citra negatif produk budaya massa terjadi antar individu dalam bentuk pergunjingan sehari-hari, bisa dalam lingkup keluarga ataupun antar masyarakat pelaku seni yang satu dengan yang lain, dan terjadi secara tidak sistemik.

Bersifat oportunistik, dan mementingkan diri sendiri merupakan poin resistensi tertutup yang kedua. Kebudayaan masa dengan produk-produk konsumtifnya merupakan sebuah hal yang dibiarkan begitu saja dan tak berpengaruh bagi in-dividu dalam anggota Laras Madya, jika sama sekali tidak menguntungkan masing-masing pribadi. Motivasi individu pelaku Laras madya tidak menganggap produk budaya massa sebagai komoditi yang pen-ting dan menguntungkan untuk dilakukan.

Poin ketiga bentuk resistensi tertutup dicirikan dengan tindakan yang tidak berkonsekuensi revolusioner. Penci-traan negatif yang dilakukan secara personal pelaku Laras Madya terhadap do-minasi budaya massa, dengan produk konsumerisme pada media-media dilaku-kan melalui pencitraan negatif/gosip yang sebagian faktual, tetapi tidak jarang hanya didasarkan rumor atau kabar yang sulit diverifikasi kebenarannya. Hal tersebut hanya tersampaikan untuk sebuah pergun-jinganpergunjingan ringan yang tidak ber-tujuan sebagai misi perubahan besar pada kondisi sosial budaya yang melingkupinya.

Aspek keempat resistensi tertutup dilakukan dengan lebih akomodatif terhadap sistem dominasi. Para pelaku Laras Madya pada dasarnya bersifat menyesuaikan diri dari klas dominasi. Kendati posisi Laras Madya dan pelaku-pelakunya ada dalam himpitan hegemoni budaya massa yang ada, namun tidak sepenuhnya antipati pada komoditi-komoditi konsumerisme pada media. Pelaku Laras Madya dan kubu tradisi tentu tak lepas dari agen-agen klas dominasi melalui media masa dalam keseharian. Hal tersebut bukan suatu ideologi yang dapat ditelan mentah-mentah dan diikuti sebagai pengaruh. Namun dijadikan suatu bentuk hal baru dalam pengetahuan tanpa harus mengikuti arus yang dipromosikan.

Arah tujuan hegemoni budaya massa yang terdapat pada berbagai media melalui komunikasi bujuk rayu tentunya kerap mengalami gesekan makna ideologis dengan para pelaku tradisi. Penyeleweng-an-penye- 
lewengan yang terjadi bukan tak bisa teridentivikasi. Hal tersebut dapat terditeksi pelaku tradisi, dalam lingkup anggota laras madya. Bentuk perwujudan resistensi tertutup terhadap hegemoni budaya massa adalah pencitraan negatif akan berbagai pelanggaran yang terjadi. Karena sesungguhnya pelanggaran terha-dap tingkah laku yang menjadikan suatu peristiwa bernilai untuk digunjingkan (Scott, 2000:372).

\section{Penutup}

\section{Kesimpulan}

Musik Laras Madya merupakan repetisi teknik ansambel perkusif. Spesifi-kasi karakteristik instrumen diantaranya kendang berfungsi sebagai komando untuk memulai lagu, pengatur tempo, pembang-kit dinamik lagu, terbang dhana berperan sebagai penegas dari hasil olahan suara kendang, terbang gong berfungsi sebagai bass, saron dimainkan pada keutuhan lagu setiap hitungan ke 2-4 pada setiap birama, saron muncul sebagai ciri khas musik Laras Madya dengan bunyi statis "ning..nong.. ning" terusmenerus sampai lagu berakhir.

Melodi musik Laras Madya pada umumnya menggunakan tangga nada pentatonis Slendro. Secara umum harmoni musik yang terdapat dalam Laras Madya adalah harmoni horisontal. Bentuk struktur lagu Laras Madya diawali dengan suluk sebagai intro oleh Bowo, dilanjutkan feel in kendang menandai dimulainya inti lagu, diikuti instrumen musik lainnya dan berjalan sesuai patren dalam patokannya. Di penghujung lagu kendang mendireksi dan memperlambat tempo (Ritardando), lalu lagu diahiri dan ditutup dengan tabuhan terbang gong dalam satu ketukan terahir. Ekspresi yang dibawakan diawali dengan lagu yang relatif rancak/ bersemangat, (tempo moderato), lalu berangsur berganti lagu yang kian lambat dan mendayu, (Andante). Namun perbedaan tempo terjadi pada lagu-lagunya relatif konstan.
Resistensi terbuka Laras Madya terdapat pada peran dalam festival kebudayaan sebagai media sub baltern dalam menyampaikan pemikiran-pemikirannya. Bahwasanya seni tradisi memiliki nilai yang lebih bermanfaat ketimbang produk-produk budaya massa adalah upaya kam-panye atau pembentukkan opini publik, dimana kampanye atau pembentukkan opini publik me-rupakan salah satu dari upaya perlawanan terbuka yang tak lepas dari sifat-sifat organik, sistematik dan kooperatif, tidak mementingkan kepen-tingan diri sendiri, berkonsekuensi revo-lusioner, mencakup gagasan atau maksud meniadakan basis dominasi.

Resistensi tertutup dilakukan secara individual pelaku anggota musik Laras Madya melalui pencitraan negatif produk hegemoni budaya massa. Arah tujuan hegemoni budaya massa yang terdapat dalam berbagai media melalui komunikasi bujuk rayu yang ada. Hal tersebut dapat terditeksi pelaku tradisi, dalam hal ini lingkup anggota Laras Madya. Bentuk perwujudan resistensi tertutup terhadap hegemoni budaya massa adalah melalui ungkapan-ungkapan pencitraan negatif akan berbagai pelanggaran yang terjadi, melalui pola-pola yang tidak teratur, tidak sistematik, dan terjadi secara individual, bersifat oportunistik dan mementingkan diri sendiri, tidak berkonsekuensi revolusioner, lebih akomodatif terhadap sistem dominasi (Scott, 2000: xxii-iv).

\section{Saran}

Keberadaan musik Laras Madya atas resistensi yang dilakukan secara internal membutuhkan kepedulian masya-rakat sebagai pendukung lestarinya bagian kearifan lokal. Kepedulian bisa dilakukan melalui berbagai upaya, diantaranya sebagai pemerhati, ataupun sebagai penyelenggara atas keterlibatan musik Laras Madya dari skala komunitas kecil keluarga sampai komunitas besar seperti festival budaya yang ada.

Dalam dunia pendidikan, musik Laras Madya memiliki berbagai nilai positif 
yang dapat diaplikasikan. Selama ini hanya memasuki wilayah pendidikan informal turun-temurun melalui keluarga dan kekerabatan. Pemerintah terkait dapat menjadikan musik Laras Madya sebagai objek materi pendidikan non-formal maupun formal dalam upaya aplikasi nilai yang terkandung, maupun sebagai bentuk pelestarian.

\section{Referensi}

Alisjahbana. 2005. Sisi Gelap Perkembangan Kota. Yogyakarta: Laksbang Pressindo.

Barker, Chris. 2015. Cultural Studies. Yogyakarta: Kreasi Wacana.

Hauser, Arnold. 1982. The Sociology of Art. Terj. Kenneth J. Northcott. Chicago dan London: The University of Chicago Press.

Hujatnikajennong, Agung. 2006. Resistensi Gaya Hidup; Teori dan Realita. Yogyakarta: Jala Sutra.
Jamalus. 1988. Pengajaran Musik Melalui Pengalaman Musik. Jakarta: Depdikbud.

Liliweri, Alo. 2014. Pengantar Studi Kebudayaan. Bandung: Nusamedia.

Rohidi, T R. 2011. Metodologi Penelitian Seni. Semarang: CV Cipta Prima Nusantara.

Scott, James C. 1990. Domination and the Arts of Resistance; Hiddenn Trancripts. London: Yale University Press New Haven and London.

Scott, James C. 2000. Senjatanya Orang-Orang yang Kalah; Bentuk-Bentuk Resistensi Sehari-hari Kaum Tani. Jakarta: Yayasan Obor Indonesia.

Sulasman, dan Setia G, M. Si. 2013. Teori-Teori Kebudayaan. Bandung: Pustaka Setia.

Sunarto. 2014. Kebudayaan Posmodernisme: Percikan Pemikiran Baudrillard. Yogyakarta: Kanisius.

Supanggah, Rahayu. 2009. Bothekan Karawitan II: GARAP. Surakarta: Program Pascasarjana bekerja sama dengan ISI Press Surakarta. 